\title{
Textile Industry In Yorubaland: Indigenous Knowledge And Modernity In The Era Of Globalisation.
}

\author{
Adu Funmilayo Modupe (PhD) \\ Department of History and International Studies, \\ Faculty of Arts, Ekiti State University, Ado Ekiti. \\ Ajayi Adeyinka T (PhD) \\ Department of History and International Studies, \\ Faculty of Arts, Ekiti State University, Ado Ekiti. \\ Aremu, Johnson Olaosebikan (PhD) \\ Department of History and International Studies, \\ Faculty of Arts, Ekiti State University, Ado Ekiti.
}

\begin{abstract}
Globalization it is accepted has made nonsense of state boarders. Issues that are local have become notable international concerns. Indigenous knowledge systems have not only been impacted by this phenomenon but have impacted other civilizations through the wildfire use of technology made available by globalization impacts. Modernity, by producing more refined and better accepted usable have brought indigenous knowledge of civilizations to the awareness of other civilizations, cross weaving technologies to produce a new and modern conception that is better acceptable and more widely distributed. The traditional Yoruba aso oke is a product with such impact, having experienced a stage of modernization resulting from technological innovations made available from other nations through the benefits of globalization. Machines of various varieties such as tread making machines, industrial weaving machines, embroidery machines amongst others, have brought modernization to the Yoruba traditional weaving industry. This has not only created a smoother and better accepted version but also an increased distribution to provide a source of livelihood for a growing population of the citizens who engage in production and distribution in Nigeria and outside. This paper argues that the Yoruba weaving industry has been positively impacted by the globalization advantage to produce a more acceptable quality that has furthered the economic interest of the industry and internationalized the awareness of a growing traditional weaving textile industry that can further be exploited for national development.
\end{abstract}

Key Words: Textile Industry, Yorubaland, Indigenous Knowledge, Modernity, Globalization.

\section{INTRODUCTION}

The textile industry in Yoruba land has been sustained for centuries. Its origin is traced to ancient immigrants from defunct empires of the Sudanese region. Ajayi (2000:70) asserted that, by the $16^{\text {th }}$ century, cotton had become a major agricultural produce among Nigerian peoples. The production, weaving and dying of this locally processed clothing had also become famous. Interestingly, an export trade in locally produced cotton items was already in existence at the advent of the first Europeans. In this wise Ajayi $(2000: 70)$ argued.

By the 16th century, many parts of Nigeria were growing cotton in abundance and had become famous for their excellent indigenous cloth. In fact, an export trade in the cotton industry was already in existence before the advent of the European explorers 
and traders. That a flourishing industry existed in those days in the manufacturing of hand woven cloth from local cotton, dyed with local dyes and indigo is shown in the diaries and references of the first European explorers and traders........it was not simply an industry or a trade, cloth weaving was a technology evolved by the people in response to the demand of the environment. For centuries, weavers, spinners and dyers collectively produced cloth for subsistence and for trade between and beyond Yoruba communities.

Interestingly, scholars (Afigbo, 1990, Ajayi et al, 1980, Ade Ajayi, 2004)have argued that, the weaving industry in Nigeria was at its peak of development on the eve of colonial governance. This notwithstanding, this paper argues that the impact of globalization and technology on this industry has made that idea a game incomparable to the new inflow of ideas and finesse, models, machines, productions, designs and distributions which can only be appreciated in view of its wide acceptance, usage, distribution nationally and internationally.

The advent of globalised technology with its varied computerization of several aspects of the production process in industrial technology did not leave this industry without an impact. In the area of production of looms and cotton thread and dying, fine industrial processing has refined the local procedures; producing an end product that could compete with any international standard available. The weaving process to some varied level have, however, retained much of the local content but a level of expanded production process has increased weavers joint weaving procedures for better production advantages.

Importation of weaving machines have also resulted in some modern concepts of specially produced versions for ceremonial and royal wears (Such are Aso Oke handcuts), embroidery machines are introduced in making special patterns on woven materials and in recent times, the adornment of decorative stones and beads have attained a wider variegation, increasing acceptability locally and internationally. In the distribution sector and at different stages, computers (the use of the internet or social media; available mediums such as the facebook, whatshapp, and telephones, instagram are highly contributive) and other mediums have provided a good advantage for designing and production and marketing of the finished goods.

Special qualities such as the new Jawu and loom, Aso Ide or onide and some other varieties now adorn ceremonial occasions across continents. Aso Oke shops can now be found in Dubai Emirate, New York, Maryland and London and elsewhere. It is therefore important to note that, the textile industry in Yoruba land has produced a blend of indigenous knowledge and modernity in the era of globalization. This paper is subsequently divided into five sections namely: conceptual clarifications, the textile industry in Yoruba land from the pre-colonial to present, Yoruba textile industry and modernity in the era of globalization, the future of Yoruba textile industry and conclusion

\section{CONCEPTUAL CLARIFICATIONS: INDIGENOUS KNOWLEDGE, MODERNITY AND GLOBALISATION.}

Indigenous Knowledge systems (IKS) are knowledge unique to a given culture or society. The widespread study of Indigenous Knowledge systems accept the idea that development efforts that ignore local circumstances, local technologies, and local systems of knowledge have wasted enormous amount of time and resources and would yield little success. This traditional approach usually examines problems in their entirety, together with their linkages and complexities relying on traditional values and the people, the culture, the knowledge they possess, their way of life etc. Globalization however hypes the importance and network of interchange. Information is diffused from one state or country to another and the influence and 
impact does not allow retention of local uniqueness. But in some instances the outcome of a newer version is better accepted.

The first acceptable characteristic of indigenous knowledge is the component of knowledge from previous generations. Woodley (1991) noted that, the knowledge set is influenced by the previous generation's observations and experiment and provides an inherent connection to ones surroundings and environment. The knowledge is characteristic of the local climate, flora and fauna, and cultural traits (Woodley, 173-178). It is further asserted that, indigenous knowledge systems is not transferable but provides relationship that connects people directly to their environment and the changes that occur within it. Further, indigenous knowledge systems is learned and identified by communities and people within a cultural context (Fields, 1991 and Bebbington, 1991). They (ibid) noted emphatically that, this knowledge base is transcribed and understood by participants through actions, such as, production, methods, verbal through sayings and myths or cultural events which are unique to the community and environment.

It is a muted idea that, with the advent of globalization, many subsistence societies are fusing modern technologies with their traditional practices- Therefore knowledge systems in a locale are influenced by "immutable mobiles" and adapted ...many cultures adapt certain aspects of this knowledge base to the characteristic in the zone (Gade, 1992, Bebbington, 1991). The final method of modifying local knowledge systems is with the incorporation of ideas into existing knowledge system. Aso Oke production in Yoruba land as understood by participants through actions such as production methods and cultural events which are unique to the community and environment follow these adaptations. The advent of globalization has further enabled the fusing of modern technologies with this traditional production practices and has become adapted. Modern ideas are also incorporated into existing knowledge systems to produce a new version that has further developed the economic interest of the industry. A Modern conception of aso oke relates to the contemporary conception. This is in comparison to the old /ancient or previous and different in terms of applications of accessories and sometimes design. Modernity is perceived in the context of change from an older trend to a more contemporary acceptable pattern or designs in aso oke: in context, its production, design and marketing strategies. The word modern in its grammatical context is defined as something or occurrence of a present or recent time or times, of styles, in art, music, fashion, new and intended to be different from traditional styles. Modernity connotes contemporary, the condition of being new or modern.

In defining globalization, various scholars have acceded to the idea of space/time compression (Brown, 1995, Anderson and O'Dowd, 1999). In modern and post modern literature, technology in its various forms is necessary for development and has accelerated the varied conceptions of globalization of international relations especially in the area of economic relations. The globalization of different aspects of state and society in its various manifestations would not have occurred without the input of scientific and technological and accompanying structural changes. Pearson and Payaslian (1999) explained that science and technology are said to be inherently transnational, integral to the internationalization of the economic transformation of states especially through the influence of telecommunications technologies.

Orubuloye (2005) agrees with Grint on the fact that globalization is the capitalist enterprise envisioning the whole world as a unified system of the area and the peripheries, with the peripheries aspiring to adopt the political economy of the former and with the gradual internationalization of the Euro-American socio-political, economic and technological cultures. 
It is further explained as the gradual connection between different societies (Grint, 1998:28) (Mc Michael, 1996:38 cited in Orubuloye, 2005).

Assessing the politics of globalised science and technology, Pearson and Payaslian (1999) asserted that a fact of modern and "post- modern" life lay emphasis on the positive impact of technology on economic development, while further explaining that telecommunication technologies have accelerated the globalization of international relations albeit in the constant promotion of indigenous knowledge networking.. In line with this, they reiterated that;

The globalization of the world political economy in its various manifestations ... would not have occurred without the scientific and technological and accompanying structural changes experienced at least since the emergence of the modern nation state in the sixteenth and seventeenth centuries (Pearson and Payaslian, 1999:271275).

Pearson and Payaslian (1999) further emphasized that, from the Nation state perspective, the centrality of science and technology in modern political economy is problematic. Weighing a two side to the coin, they argued:

On the one hand, science and technology, are the foundations for the structures of national industrial production, capital, and information capabilities, all of which contribute to national economic and military power and security; yet in facilitating the internationalization of economic relations, they also challenge the sovereignty of the nation-state. (Pearson and Payaslian, 1999:271-30).

The impact of technology has also influenced the interactions from outside the state, Cuko and Traore (2011) supported this view, when they noted that: "The cumulative effect of transnational science and technology (also referred to as globalization) has been to deterritorialise some of the activities and processes that influence our life in contemporary states". The time space compress and comparison with its localizing effect has created the possibility of instant communication between any one place on the earth's surface and any other. (Taylor, 2005:17-18).

Cultural homogenization is also a popularly acclaimed area of impact, the convergence in lifestyle and cultural values, icons and designs, similar food, and clothing (Taylor, 2005:19, 20). Globalization is an ideology that re-enacts a dictatorial unipolarism (Sara Cuko and Traore, 2011:6). They (ibid) insist that, it is the dramatic transformation in information and communication technology, in transport, financial and human mobility, and the economic restructuring reducing the significance of state borders. It is the gradual connection between different societies (Grint, 1998). The UNDP (1999) adopts the view that globalization is the growing interdependence of the world's people through "shrinking space, shrinking time and disappearing borders". This connotes an instantaneous satellite communication networking and a dramatic advancement in communication information technology and transportation amongst others. Adefolaju (2005) commented further that globalization therefore offers great opportunities for enriching peoples' lives and creating a global community based on shared values. It translates to the integration of economic, political, civil and technological structures around the world (Umukoro, 2002). Adefolaju reiterated further that, it was the response of states to the apparent inadequacy of nation states to tackle many contemporary issues facing them (Adefolaju, 2005:139). It is also defined as a process fuelled by and resulting in, increasing cross-border flows of goods, services, money, people, information and culture. This is global interdependence amongst actors (individual, groups, and nations) and mutual awareness among economic, political, and social units in the world. 
In the instance of this research (i.e the Nigerian case study), the influence of technology in indigenous aso oke production and distribution is crucial in giving a transnational dimension to internal affairs of the state in respect of economic issues of trade. The internet provides a transnational communication device to promote economic network and encourage cultural and technological borrowings in production processes and design. It is important to highlight that there are divergent views from schools of thought regarding the concept of globalization which range from realist, liberals to historical structuralisms. The point of diversions however, is that the realist acknowledges the increasing pace of globalization which is at the instance of the most powerful states (Boyer and Drache, 1996, Hirst and Thompson, 1999). Liberals, in contrast, believe globalization, at a significant level, is eroding state control, but the growth of global interdependence is positive - thus, they highlight the importance of technological changes and advances in communication and transportation that are beyond state control. They (liberals) emphasize societal actors such as transnational firms and domestic citizens (Milner, 1988 cited in Adu, 2016). This is referred to as a focus on the "borderless world" - a world in which obvious market forces influence issues far more than National government (Ohmae, 1990, 1995). In the instance of the liberals, it is believed that there is a significant level of globalised state control erosion, but the growth of global interdependence is a positive development. To this group, technological change and advances in communications and transportation that are beyond state control is the main focus.

Liberals see globalization as leading to a "borderless world" in which market forces are superior to National governments (Ohmae, 1990, 1995). Historical structuralisms argue that though globalization is having a significant positive impact, it has extremely negative consequences for the poorer states and classes in the periphery of the global economy. The dependency school of economics agrees with the analysis of Steven and David, (1993 cited in Ohame, ibid) that globalization is leading to the development of a "transnational historical block" composed of the multinational corporations (MNCS) International Banks, International Economic Organizations (World Bank and IMF) and International Business Group in the most powerful capitalist states. Globalization is a process of interaction and integration among the people, companies and governments of different nations, a process driven by international trade and investments and aided by information technology with effects on the environment, on culture, on political systems, on economic development, and prosperity and on human physical well-being in societies around the world (ibid). Globalization is not new however, because many of the features of the current wave of globalization are similar to those prevailing before the First World War in 1914 (ibid).

Bauman (1998) assessed globalization through the social roots and consequences of the globalizing process. For globalization, the causes of division are identical with those which promote the uniformity of the globe (Bauman, 1998: 4-10). It is a two-sided coin which appears to different people from dimensions and points of vantage. In this wise, Bauman (ibid) noted "what appears as globalization for some means localization for others signaling a new freedom for some, upon many others it descends as an uninvited and cruel fate. Analyzing the spate of the historically changing nature of time and space within the premise of pattern and scale of social organization, the stages of development from the past to present within the modern pattern of social control, the idea of political sovereignty under conditions of globalised economy, finance and information, the cultural consequences of the transformations in globalization present itself. Adeyanju (2006) noted that state territoriality is being reconfigured by issues of globalised capital market operations, the integrated system of production and consumption, international labour mobility, diminishing state control of flows across its boundaries, among other issues( ibid:141-142). 


\section{TEXTILE INDUSTRY IN YORUBALAND FROM THE PRECOLONIAL TO PRESENT}

Cloth making and its use is one evidence of a civilization achievement. Archeology, written and oral sources attest to weaving as an ancient local craft of repute. Traditional Yoruba spatial conceptions attest to the idea that the evolution of the weaving industry in Nigeria must have resulted from the need to cover the body for protection and aesthetics. The weaving industry was an important economic resource, a means of adornment and an art for the Yoruba cultural group. Ajayi(2005:73) insists that, weaving was not simply an industry, or a trade, but a technology evolved by the people in response to the demands of their environment. Traditional weaving was done within the household, involving majorly women and in eastern Yoruba land men who produced at commercial levels and also the children who assisted in the winding of yarn. Pre colonial weaving industry manufactured for immediate local consumption and few sales transcending the annexing markets in neighboring towns and villages...

The weaving industry spread from the dying Sudanese empires such as Mali where a cotton industry existed in the $14^{\text {th }}$ century (ibid). The $16^{\text {th }}$ century showed widespread cotton farming across Yoruba land and Nigeria. This product attained international reputation as exportation of cotton was already a common trade before the advent of the Europeans explorers and traders (Ajayi, ibid). For centuries a well organized weaving, spinning and dying industry grew in intensity. The weaving processes involved collection of fiber, soaking, cleaning and spinning and weaving. Dying is a second process sometimes handled by another artisan. Dyes are extracted from plants and must be well prepared to ensure its quality. Interestingly, the quality of textile influenced by early European contact attracted orders from private individuals in the United States, the United Kingdom, the Jos Museum and experimental orders for UAC car seat cover production in Nigeria. The increasing competition with European textile made the colonial government present a lackadaisical attitude towards encouraging further growth in production. The increase in demand for European fabrics killed the fledgling industry.

The survival of the weaving industry was dependent on patronage. The industry however maintained a strong survival spirit, in the post colonial era as ceremonial wears retained a pride of place among the Yoruba. This trend was further promoted in the post independent era in Nigeria. This trend continued into the expanded and reintroduction of Aso ebi. The modernization of aso oke into several finely refined items of a wide variety, with a quality to gain international repute, has brought the revival of this important industry. The beautiful array of colours and varieties in festivals and family functions attest to the growing reputation of the aso oke. European shopping malls adorn cities such as New York, London and Dubai as evidence of the growing reputation.

\section{YORUBA TEXTILE INDUSTRY (ASO OKE) AND MODERNITY IN THE ERA OF GLOBALISATION}

The textile industry in Yoruba land comprises the production in aso oke and adire(or batik). Aso oke however dominated the environment of class, fashion, festivals, and royal adornments. The aso oke usages in Yoruba land spread between the everyday usage-(providing warmth in the cold days of the harmathan period) and adornment as regalia for royalty (for example, Kings, princes, and chiefs adorn it as ceremonial wears) adornment as festival clothing in weddings, burials, chieftaincies, religious and other festival celebration clothing's (important festivals such as the new yam festivals, Egungun, and worship of gods and ancestors) and other important functions. This important relevance has necessitated the emergence and growth of the aso oke production to sustain the industry.

The Yoruba textile industry has existed from time immemorial. Pre colonial Aso oke production served the varied needs of the Yoruba society. In the post colonial period, and with the advent 
of globalised technological advantages, aso oke production, marketing and usages have been positively impacted upon, expanding the industry within and outside the country, and enlisting it as a local industry of repute and a contributor to the country's GDP and national development.

The modernization of aso oke production has encompassed the intervention of finely produced treading loom (in the past, hand spinning of wool through the thread loom was the order of the day ( Adu, one of the authors had witnessed the local spinning of wool from harvested cotton by her grandmother)also the local weaving procedure, using what is locally termed apasa or vertical loom was later replaced by the horizontal loom. Industrial production of tread has increased availability and promoted quality. It has given opportunity to produce more and better varieties. Dying is now processed through industrial manipulations (in the ancient times, few colours such as white, black and blue were available) presently, there are several colours and shades provided to meet individual and group interest to ease patronage.

Production techniques have also been improved upon as the wooding threading loom was switched to a metal addition technology and presently, industrial machines are in use. Further some of these threads are imported from China. Cloth weaving was a technology evolved by the people of Yoruba land as a response to the demands of the tribal environment. From time immemorial, spinning, dying and weaving was usually done by one person. This was because subsistence production was minimal to the local population. With trade and technology, units of production could sometimes be given to sections of the industry. For example, thread making industries provide colourful treads already in spinned balls ready for weaving. The intricately designed aso oke is evidence of high level production. In the pre colonial days, different materials, machinery and terms of labour were utilized. Ajayi (in Olaoye, undated) emphasized that,

Indeed, technology was involved in various processes in manufacturing fabrics. The entire process of textile manufacture demanded expertise in a variety of processes, collection of fiber, soaking, cleaning, and spinning and their reconstitution and elaboration through weaving, dying involved considerable skills in the technology and chemistry of colours (Ibid :71).

Ajayi further noted that,

Dyes were extracted from barks, wood, roots, fruits and leaves. Technology was involved in the preparation of the dye and binding it to the material such that it does not damage the fiber and retains permanent coloration throughout the useful life of the fabric as skills by individual artisans, or by a group of collectivized artisans within the industrial process, artisans who apply technology to make things that become part of living, part of life.(ibid:71-72).

European hand weaving technology was introduced into Nigeria in the mid 1940s (NAI, Ondo Prof 1/1 1836B, Textile Centre, Ado Ekiti, 1949:1). This was referred to as a phase of modernization of the local textile industry. The objective was to introduce improved equipment and new techniques to train spinners, weavers and dyers to add value to indigenous methods of cloth production. The output of this was a high quality Aso oke which attracted orders from sources such as the United States, United Kingdom (British members of parliament) the Jos Museum, UAC Lagos (for car seats covers) etc.(See Ajayi, ibid). Gradual growth in demand stimulated interest in textile production generally, leading to the establishment of a Nigerian textile industry in Kano and Lagos in 1949 (See Ajayi, ibid:75). These two mills were unfortunately closed down by 1951 due to some challenges of colonial 
policy which discouraged local technological development to prevent competition with European goods.

Increased demand for the European type fabric surpassed that of the local industry by 1952 for a new technological innovation to be internalized, it must fulfill the need of the people. Technology can only be absorbed and grow if planted within a pre existing culture. Ade Ajayi (2004:160-161) argued that,

You cannot borrow some technology, you can begin by imitating some aspects of other people's technology, you can even try to transfer technology, but technology cannot develop... it cannot grow outside the context of culture..... The experiments, inventions and patents grow only when they are acquired.

It is important herewith to note that, the failures of the colonial textile scheme was a success in the post independence era as aso oke production has achieved an enviable position in the satisfaction of the locale and export trade (in the era of globalization) thus positively impacting economic development.

\section{THE FUTURE OF YORUBA TEXTILE INDUSTRY}

A visitor to a Yoruba cultural ceremony will attest to the high importance placed on the use of aso oke. The beauty and elegance of this clothing has attracted tourists to several traditional functions. The new trend in aso oke fashion has brought new dimensions of stone decorations, fashionable embroideries and lace pattern formations that has enhanced the beauty and elegance of the aso oke. Other softer varieties produced for easy tying has further increased the appeal of aso oke to the youth and the younger generation. The industry is increasing in participation as new entrants (at the production and marketing level) are within the younger generation, ensuring a future and continuity. The designing is taken up by another group of interested artisans, while the marketing aspect has gone beyond the shores of Yoruba land to areas beyond the borders of Nigeria and the world. Europeans with cultural fascination have decked aso oke attires to the delight of Nigerians. This is to show that a good future awaits the industry.

Interestingly, a Chinese machine woven variety was introduced into Nigeria in about 2014, but did not retain popularity though it is still being sold; the locally produced versions have continued to hold sway in local festivities. It is important to state that there is no limit to the dimensions of produced varieties as new designs, textures and innovations are added to titillate patronage.

\section{CONCLUSION}

In the era of globalization, the Yoruba aso oke has received impressive attention, a boost that has promoted the industry and internationalized its sales at a growing momentum across the globe. Indigenous knowledge systems have not only been impacted by this phenomenon (globalization) but have impacted other civilizations through the wildfire use of technology made available by globalization impacts. Modernity, by producing more refined and better accepted usable have brought indigenous knowledge of civilizations to the awareness of other civilizations, cross weaving technologies to produce a new and modern conception that is better acceptable and more widely distributed. The traditional Yoruba aso oke is a product with such impact, having experienced a stage of modernization resulting from technological innovations made available from other nations through the benefits of globalization. This paper argued that, the Yoruba weaving industry has been positively impacted by the globalization advantage, to produce a more acceptable quality that has furthered the economic 
interest of the industry and internationalized the awareness of a growing traditional weaving textile industry that can further be exploited for national development.

\section{References}

Afigbo, A.E (1980), “The Eastern Provinces under Colonial Rule” in Ikime O. (ed) Groundwork of Nigeria History, Ibadan; Heinemann.

Ade Ajayi, J.E (2004), "The Cultural Factor in Technological Development" in In search of the Route to National Technological Development. A Compendium of Foundation Day Lectures, FUTA , Akure.

Adefolaju, T. (2005), "Globalization and the Emerging New Work Patterns" in Olu Olu Olufayo, (2005)(ed) Perspectives on Globalization and African Development, Ikeja, Lagos: Bolabay Publications.

Adefolaju, T. (2005), "The Cultural Dimension of Conflict and Implications for Development in Nigeria", in Agagu A.A, and Omotoso F. (ed) Introduction to Peace and Conflict Studies, The Nigerian Perspective, Ado-Ekiti: UNAD Press.

Adeyanju, C. (2006) "Yoruba - Nigerians in Toronto: Transnational Practices and Experiences", in Falola T. and Genova A. (ed), Yoruba Identity and Power Politics, Rochester: University of Rochester press.

Adu, F.M (2016), Nigerians in the Diaspora and Homeland Development, A PhD Thesis Submitted to the Department of Political Science, Ekiti State University, Ado Ekiti, Nigeria.

Agrawal, A. (1995), “Dismantling the Divide between Indigenous and Scientific Knowledge” Development and Change.26.

Aina,T. (2002), "From Colonialism to Globalization: Reflections on Issues in Transformation and Democratic Development in Africa", in Aina, Tade (eds) Globalization and Sustainable Human Development in Nigeria, Lagos: UNILAG.

Aiyedun, E.A (2004), "Nature and Meaning of Globalization", in Odama J.S. and Aiyedun.E.A (eds) Globalization and the Third World Economy, Impacts and Challenges in the 21st century, Lagos: Malthouse Press.

Ajayi, J.F.A and Alagoa, E.J (1980), "Nigeria Before 1800: Aspects of Economic Developments and Inter Group Relations" in Ikime 0. (ed) Groundwork of Nigeria History, Ibadan: Heinemann.

Ajayi, A.T (2005), "The Economics of Cloth Weaving in Ekitiland in the 20 $0^{\text {th }}$ Century", in Obitun, Journal of Humanities", Vol. 4. No.1, Petoa, Publisher.

Ajayi, A.T.(2000), “The Colonial Textile Development Scheme 1945-1950: A Horoscope for Policy Making on Industrial Development in Nigeria" in R.A Olaoye (ed), History of Indigenous Science and Technology in Nigeria. CrestHill Publishers ltd, Ibadan.

Akinrinade, S. (2004) (ed), Locating the Local in the Global: Voices on Globalised Nigeria, Faculty of Arts, OAU, IleIfe: Cedar Productions.

Akinwumi T. (2003), "Textile Craft Connections Among the Yoruba and their Neighbours in Pre Colonial Nigeria" in Akinyele, R.T(ed) Race, Ethnicity and Nation Building in Africa, Studies in Inter Group Relations, Lagos, Rex Charles Publications.

Anderson, J. and O'Dowd, L. (1999),"Contested Borders: Globalization and Ethno National Conflict in Ireland" Regional Studies, Vol.33, No.7.

Anyanwu,J.C, Oyefusi,A et al (1997), The Structure of the Nigerian Economy (1960-1997),

Bauman, Z. (1998), Globalization, the Human Consequences, New York: Columbia University Press.

Bebbington, A. (1991), "Indigenous Agricultural Knowledge Systems, Human Interests, and Critical Analysis: Reflections on Farrur Organizations in Ecuador. "Agriculture and Human Values. 8

Boyer, D. and Drache (eds) (1996), States Against Markets: The Limits of Globalization, London, Routledge.

Brown, R. (1995), "Globalization and the End of the National Project" in J. Macmillan and A. Linklater (Eds.), Boundaries in Question: New Directions in International Relations, London and New York: Printer Publication Ltd.

Cohen, R. (1995), “Rethinking “Babylon”: Iconoclastic Conceptions of the diasporic experience”, New Community, Vol. 21.

Cohen, R. (1996), 'Diasporas and the Nation state: From Victim to Challengers”, International Affairs, Vol. 72. 
Cuko, S. and Traore, M. (2011), "Diaspora Networks and Identity: Conflict Resolution in the Horn of Africa”. The Interdisciplinary Studies of International Studies, (IJIS) 5, Retrieved July 9, 2011, http://ojs.aub.aau.dk/index.php/ijis/article/view/171/112

Faluyi, E.K, (2003), “Economic Relations Between Eastern Yoruba and the Coast before 1900” in Akinyede R.T (ed), Race, Ethnicity and Nation Building in Africa, Studies in Inter Group Relations, Lagos, Rex Charles Publications.

Fields, Les. (1991), “Tools for Indigenous Agricultural Development in Latin America: An Anthropologist's Perspective" Agriculture and Human Values. 8

Gade, Daniel W. (1992), Landscape, System and Identity in the Post Conquest Andes" Annals of the Association of American Geographers. 82.

Gilroy, P. (1993), The Black Atlantic: Modernity and Double Consciousness, London: Verso.

Globalization, Stanford Encyclopedia of Philosophy, First Published June 21, 2002, Substantive Revision, Tuesday, June, 10, 2014.

Grint, K. (1998), The Sociology of Work. 2nd Edition, Cambridge Polity Press.

Herbst, J, (2005), “Africa and the Challenge of Globalization" Paper Presented at the Conference on Globalization and Economic Success; Policy Option for Africa. Singapore 7-8 November.

Hickey, S. and Mohan, G. (2003), "Relocating Participation within a Radical Politics of Development: Citizenship and Critical Modernism." Draft working paper prepared for Conference on 'Participation'. From Tyranny to Transformation? Exploring New Approaches to Participation in Development' 27-28 February 2003, University of Manchester, Manchester.

Hirst, P. and Thompson (1999), Globalization in Question: The International Economy and the Possibilities of Governance, Cambridge: Polity.

Hopkin, T. (1969),“Third World Development in Transitional Perspectives”, American Journal of Political and Social Sciences Vol. 386.

Iwara, A.U (2004), "Identity Politics, Globalization and Socio- Political Engineering in Nigeria”, in Duro Oni, et al (eds) Nigeria and Globalization Discourses on Identity Politics and Social Conflict. Lagos (CBAAC).

Legassick, M. (1976), “Perspectives on African Underdevelopment, The Journal of African History, Vol. 17. No.3, Cambridge University Press, http://www.jostor.org/stable/180703 Accessed 19-08-2015. 14:10 UTC

Majekodunmi, A and Adejuwon K (2012), "Globalization and African Political Economy: The Nigerian Experience", International Journal of Academic Research in Business and Social Sciences. August, 2012, Vol. 2, No.8. ISSN 22226990.

McMichael, P. (1996), “Globalization, Myth and Realities” in Roberts, T. and Hite, A. (ed) From Modernization to Globalization, London: Blackwell.

Mutethia, J. (2000), “Africa and Globalization” The Guardian, Aug. 15, 2000.

NAI, Ondo Prof 1/3 D .34, Development of Textile Industry, 1949.

NAI, Ondo Prof 1/1 1836B, Textile Centre, Ado Ekiti, 1949.

NAI 1949, Ondo Prof 1/3 D .34, Development of Textile Industry.

NAI, RG/ x42 (1949), Statement on the Activities of the Department of Commerce and Industries.

NAI, DCI 1/1 403 S.5,(1946), Textile Development Sectional Report,-52.

Ohmae, K. (1990), The Borderless World: Power and Strategy in the Industrial Economy, London: Collins.

Olufayo, 0.0. (ed) (2005), Perspectives on Globalization and Africa Development, Lagos: Bolabay Publications.

Olaoye, R.A (2002), "The Traditional; Cloth Weaving in Nigeria Before 1800, in G.O Oguntonusin and S.A Ajayi (ed) Readings in Nigeria History and Culture, Essays in Honour of Professor J.A Atanda, Ibadan , Hope Publications.

Orubuloye, I.O. (2005), "Globalization and the African Development” in Olu Olu Olufayo (ed) 2005, Perspective on Globalization and Africa Development, Lagos: Bolabey Productions.

Osunade, M.A, and Adewole, (1994),"Indigenous Climate Knowledge and Agricultural Practices in Southwestern Nigeria" Malaysian Journal of Tropical Geography. 
Quattara, A.D (1997), " The Challenges of Globalization for Africa” Address at the Southern Africa Economic Summit Sponsored by the World Economic Forum, Harare, May 21, 1997, available online at http://www.imf.org/external/np/speeches/1997/052197.htm.

Pearson, S.F. and Payaslian, S. (1999), International Political Economy: Conflict and Cooperation in the Global System, United States: McGraw-Hill College.

Raufu, A.(2001), "See what globalization has done to us", Nigerian Tribune, Tuesday,29th April.

Rugumamu, S.M (2001), Globalization and Africa's Future: Towards Structural Stability, Integration and Sustainable Development. Harare: AJPS.

Smelser, N. (1964), "Towards a Theory of Modernization", in Etziani, A. and Etziani, E. (eds) Social Change; Sources, Pattern and Consequences, New York: Basic Books.

Soludo C. (2013), "Is Nigeria Losing Her 17 Million Diasporas? The Soludo Solution", ThisDay Live, $4^{\text {th }}$ Feb. 2013 retrieved 8/7/13, http://www.thisdaylive.com/articles/is-nigeria-losing-her-17-million-diaspora-/138311/

Stalker, P. (2000), Workers Without frontiers: The Impact of Globalization on International Migration, Geneva: International Labour Organization.

Taylor, P. (2005), International Organization in the Age of Globalization, New York \& London: Continuum.

The Challenge of Development: World Development Report 1991. https://openknowledge.worldbank.org/bitstream/handle/10986/5974/WDR\%201991\%20\%20English.pdf?sequence=1 Retrieved $16^{\text {th }}$ November, 2011.

Titilola, S. Oguntunji and David Marsden (1995), "Indigenous Knowledge as Reflected in Agriculture and Rural Development". The Culture Dimension of Development: Indigenous Knowledge Systems, London: Intermediate Technology Publications 1995, (ed.) D.Michael Warren. L.Jan Silkkerveer, and David Brokensha.

UNDP, (1999), Human Development Report 1999, New York.

Woodley, E. (1991),"Indigenous Ecological Knowledge Systems and Development" Agriculture and Human Values, 8. Xin, R.K (1994), Case Study Research: Design and Methods. Second Edition, Sage Productions, London. 